\title{
Private Sector in Public Policy-An Analysis of Private Sector Involvement in Corona Virus Testing
}

\author{
Gbenga Ayodeji Osinowo \\ Paradigms Learning Center LLC, Lawrenceville, USA \\ Email: ayoparadigms@gmail.com
}

How to cite this paper: Osinowo, G. A. (2021). Private Sector in Public Policy-An Analysis of Private Sector Involvement in Corona Virus Testing. Open Journal of Social Sciences, 9, 103-117.

https://doi.org/10.4236/jss.2021.912009

Received: November 8, 2021

Accepted: December 5, 2021

Published: December 8, 2021

Copyright $\odot 2021$ by author(s) and Scientific Research Publishing Inc. This work is licensed under the Creative Commons Attribution International License (CC BY 4.0).

http://creativecommons.org/licenses/by/4.0/

\begin{abstract}
The federal government delayed incorporating the private sector in the coronavirus testing of the people. As a result, early detection of coronavirus cases was hampered in the United States of America. The purpose of this qualitative, case study was to investigate the synergy between the public and private sectors in coronavirus testing. Secondary data were collected regarding the private sector involvement in coronavirus testing through media reports, corporate records, and credible news sources. These data were compiled as raw data and developed into codes, which led to categories and eventually developed into themes. Findings indicate that the delay in the private sector coronavirus testing was due to the government's quest for political gain to guarantee reelection and the incompetence of the government that could not incorporate and coordinate the early inclusion of the private sector effectively. The findings also show how the government delayed the private sector in coronavirus testing via a rigid governmental control that prevented coronavirus testing at the early stages of the pandemic. The positive policy change of this study recommends adequate mechanisms to guarantee easy integration and coordination between the private and the public sectors in public policy. Also, this paper's positive social change implication shows that it is compulsory to include the private sector in public policy process, because their expertise is needed to provide expedited public policy to cater to the needs of society.
\end{abstract}

\section{Keywords}

Corona Virus Testing, Private Sector, Public Sector, Public Policy

\section{Introduction}

The purpose of this paper was to investigate the synergy between the public and 
private sectors in coronavirus testing. I explored the activities of the private sectors in the coronavirus testing during President Donald Trump's administration in the United States of America. The scope of the study was to concentrate on the private sector involvement in coronavirus testing at the early stages of the pandemic, and the paper did not reflect on the overall activities of the private sector activities in coronavirus testing during the Trump administration. World Health Organization (2021) defined coronavirus disease (COVID-19) as an infectious disease caused by a newly discovered coronavirus that is more deadly to older people with underlying medical problems. Most people infected will experience mild respiratory illness and recover without needing any special treatment. Centers for Disease Control and Prevention (2020) traced the origin of COVID-19 to Wuhan, China, in December 2019, and informed that coronaviruses are from a large family of viruses commonly found in people and animals, with COVID 19 as the latest coronavirus discovered.

Hyman (2014) explained that the core value of the private sector is efficiency, while the public sector is guided on both values of equity and efficiency. It might then be assumed that public policy is solely determined and implemented by the government, because the philosophical justification of the public sector based on both principles of equity and efficiency is controlled exclusively by the government. Hence, few studies have examined the extent/influence of the private sector in public policy formulation, execution and evaluation. By reviewing the coronavirus pandemic in a case study, this paper addressed the private sectors' involvement in providing adequate testing ability/facilities for coronavirus. This paper showed that the private sector is relevant to public policy because of the close relationships between the private and the public sectors in public policy formulation and implementation.

Osinowo (2019) postulated that "it was necessary to include private sector analysis in a comprehensive review of public policy because inter-dependencies of the private-public sector guarantee effective public policy implementation/ assessment." The COVID 19 pandemic provided an avenue to test how the private sector is relevant to public policy. The problem statement is to determine the delay/lack of delay in the private sectors coronavirus testing activities in the United States of America. And the research questions are: why did the private sector get delayed/not get delayed in coronavirus testing? And how did the private sector get delayed/not delayed in coronavirus testing? And the goal of the paper was to help to cement or reject the need for the private sector in public policy by using coronavirus testing as the unit of analysis.

\section{Method}

The research method employed for the paper is qualitative because the research required the need to understand the "why" and "how" the private sector got delayed/not delayed in coronavirus testing. Creswell (2009) explained that qualitative research is a means to explore and understand the meaning that individuals 
or groups ascribe to a social or human problem. The paper investigated the private sector involvement in coronavirus testing, which made the qualitative method as the most appropriate research method, as the data was qualified and not quantified.

The research approach was the use of a case study approach which provided a detailed explanation of the private sector in coronavirus testing. Yin (2014) explained that case studies are the preferred strategy to understand the how and why of a research question and when a researcher has little control over the events and when the focus is on contemporaneous events with real-life consequences. The coronavirus testing is a contemporaneous event with real-life consequences, and I possess little or no control over the event, which made the case study the most appropriate for the conduct of the research.

\section{Data Collection}

The data-collection strategy was content analyses of the media reports regarding coronavirus testing. Creswell (2013) outlined the features of case studies to include, an in-depth understanding of the case, a description of the case, and the researcher's conclusion are informed by the overall meaning derived from the case. I identified a specific case of coronavirus testing, used content analysis to understand why and how the private sector got involved. At the same time, inferences were drawn from the data obtained to answer the research questions.

I am a scholar who is interested in the area of public-private sector collaboration and cooperation. I possess enormous practical experience in the private sector, and my academic background in public administration gives me an interest in public-private sector analysis. I had prior experience in public-private analysis when I researched the involvement of the private sector in the National Security Agency (NSA) Surveillance Programs (Osinowo, 2019). In this paper, using the private sector involvement in coronavirus testing has helped to test the validity of the conclusion of my prior research. The research asserts that it is necessary to include the private sector in a comprehensive review of public policy because inter-dependencies of the private-public sector guarantee effective public policy implementation/assessment. This paper also offered more insights into the need to get the private sector involved in public policy quickly.

The data collection was the creation of raw data from articles that documented the involvement of the private sector in coronavirus testing. I used the raw data in the identified articles to identify contents, statements, and quotations to draw patterns and comparisons to develop codes, categories, and themes. The point of saturation was determined when all the articles were trending towards the same conclusion.

\section{Analysis}

The secondary data of the identified articles were named sources of raw data and eventually transformed into code in line with Liamputtong and Ezzy's (2005) recommendation. Saldana (2013) recommended developing code to category, 
and transition into themes concluded the data design. The data coding was via manual coding in a tabular form, which I did because the data was relatively small. I possess prior experience in manual coding through past research. All coding emerged from the analyses of the data collected to answer the research questions of why and how the private sector got delayed/not delayed in coronavirus testing. I created two tables to analyze the research questions; Table 1 showed the reasons why there was a delay in the private sector involvement in the coronavirus testing. Table 2 showed how the private sector got delayed in the coronavirus testing.

The two tables above showed the progression from the sources of information which were inductively used to code, which resulted into categories and eventually led to themes. It was a rigorous process whereby I sought articles that reported on coronavirus testing in the United States of America. I was then able to condense the relevant information regarding the delay/lack of delay in the private sector involvement in the coronavirus testing. Basit (2003) stated that the choice between manual coding and electronic coding is dependent on the size of the project, the funds and time available, and the researcher's expertise. I manually coded the information from the sources because the data were relatively small, which developed into categories and eventually led to themes.

I discovered three themes from the analysis of the data derived from the relevant sources of information. Two themes showed why there was a delay in the private sector involvement in coronavirus testing. In contrast, the third theme showed how the private sector got delayed in coronavirus testing.

- The first code discovered was that the government downplayed the effects of coronavirus/exaggerated their plans and successes regarding coronavirus testing. The data further suggested that the government became complacent about coronavirus, which led to complacency as a category before it later transitioned into the theme of political gain/guarantee re-election.

- The second code discovered from the sources of information was a rigid governmental regulation that led to the delay of the private sector in coronavirus testing, which made the coronavirus testing process disorganized as a category. It eventually transitioned to the theme of incompetence by the government.

- The third code discovered from the sources of information was the over-reliance on the Centers for Disease Control and Prevention (CDC) as the only coronavirus testing organization at the early stages of the pandemic, which was due to high handedness of government officials/parastatals as a category, which was attributed to a rigid governmental control as a theme.

The credibility of the research was ensured via the use of reflexibility approach whereby my past experiences, values, and biases were not used to color the creation of the raw data as a secondary source of data, which also minimizes the use of value judgment. The transferability of the research was ensured via the use of triangulation, whereby multiple secondary sources provided data that provided 
Table 1. Representation of why the private sector is being delayed in the coronavirus testing.

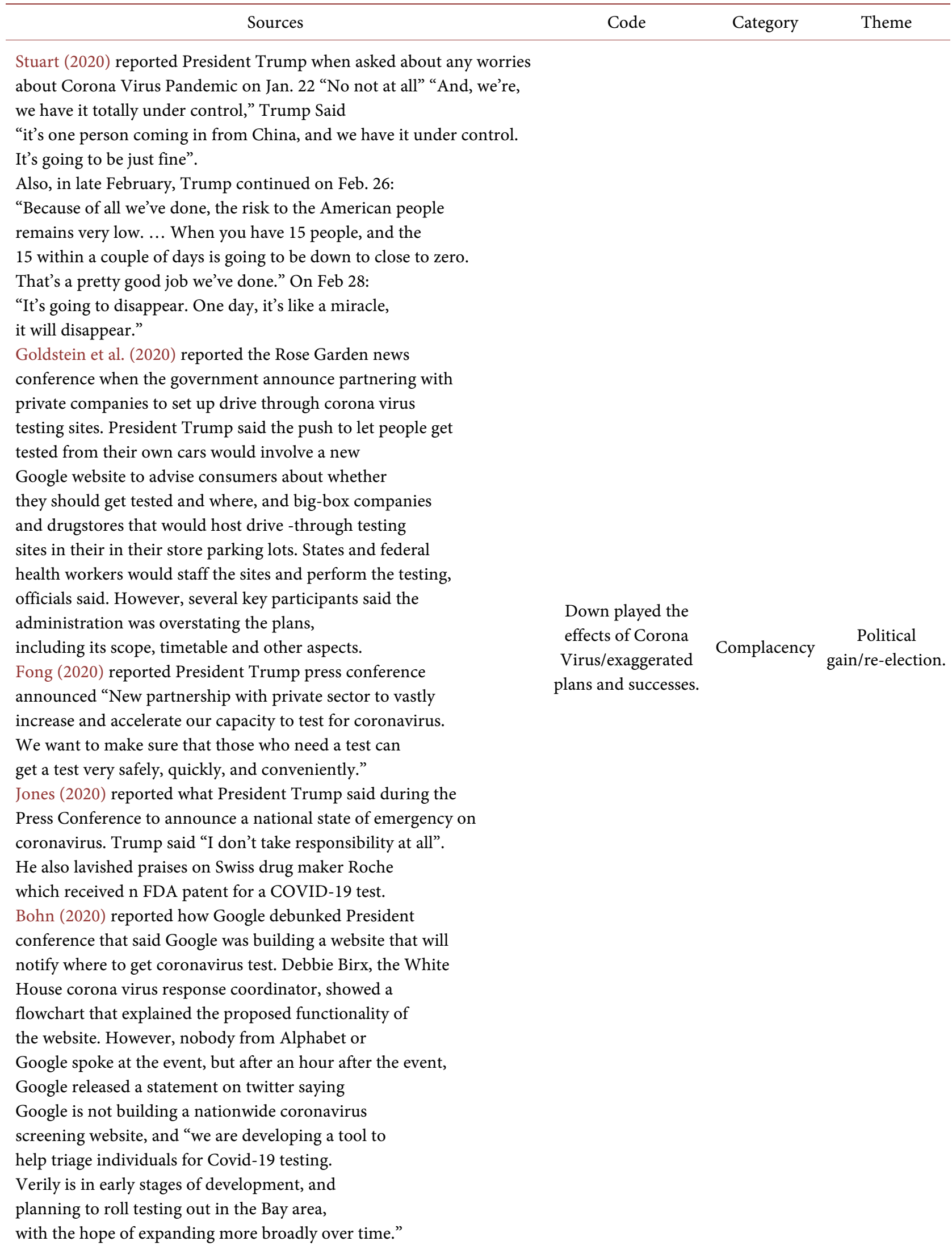




\section{Continued}

Stuart (2020) reported the United States initial over-reliance on the Centers for Disease Control and Prevention (CDC) and the Food and Drug Administration was to block private testing. Bloomberg details how the feds failed to take advantage of the private sector. Singer (2020) reported what Jeffrey A. Singer, general surgeon described the chaos and disorganization that characterized the Corona Virus testing in United States due to bureaucracy. He explained that rigid federal regulatory regime fails to make use of the innovation, flexibility and speed of the private sector is largely to blame. Court (2020) reported that Washington missed an early opportunity to leverage the resources of the private sector. Instead, health authorities were left with a diagnostic tool developed by the U.S. Center for Disease Control and Prevention that ran into weeks of problems, hobbling efforts to track and control the virus at a time when it might have been contained.

Burton (2020) reported Dr. Stephen Hahn of the Food and Drug Administration Commissioner announced the flexible regulatory approach to allow more private companies to conduct more test without prior approval.

Coombs (2020) reported the confusion that followed the government announcing that private labs to start testing for coronavirus, prompting concerns about cost and insurance co-pays.

Pollitz (2020) reported the surprise medical bills that might occur if patients seek testing in an emergency room, even at in-network emergency facility if physicians who work there might not be in-network, and out-of-network commercial lab despite the Congress passing the families first coronavirus Response Act which made testing available via public health departments and private laboratories. Diamond (2020) reported President Trump Rose Garden announcement on march 13 when he acknowledged that the initiative to increase testing was disappointing at the start, but he wants to preview a network of drive-thru tests in places like Walmart parking lots "The goal is for individuals to be able to drive up and be swabbed." Wamsley (2020) reported that the U.S government has been sharply criticized for its slow response to the virus, particularly when it comes to testing. Hence, the Trump administration announced a series of measures intended to speed testing by appointing a new federal coordinator to oversee testing and funding. Stebbins and Comen (2020) reported that the coronavirus pandemic has caught the govt unprepared and led to the government to enlist the private sector for help.

Ortega et al. (2020) reported weeks long coronavirus testing delay that could have been avoided had the federal agencies fully enacted their own plan to ramp up testing during a national health crisis. Like, The CDC in February releasing a flawed test which took weeks to rectify, failed to use the big commercial labs, and private labs were prevented from conducting their own tests.

Pasternack (2020) also attested to the strategic missteps and the botched rollout of the coronavirus testing. In February, U.S faces an array of problems, including a troublesome rollout of supplies and complex patchwork of rules about how these supplies can be used.
Rigid

governmental Disorganized Incompetence regulation. 
Table 2. Representation of how the private sector is being delayed in the coronavirus testing.

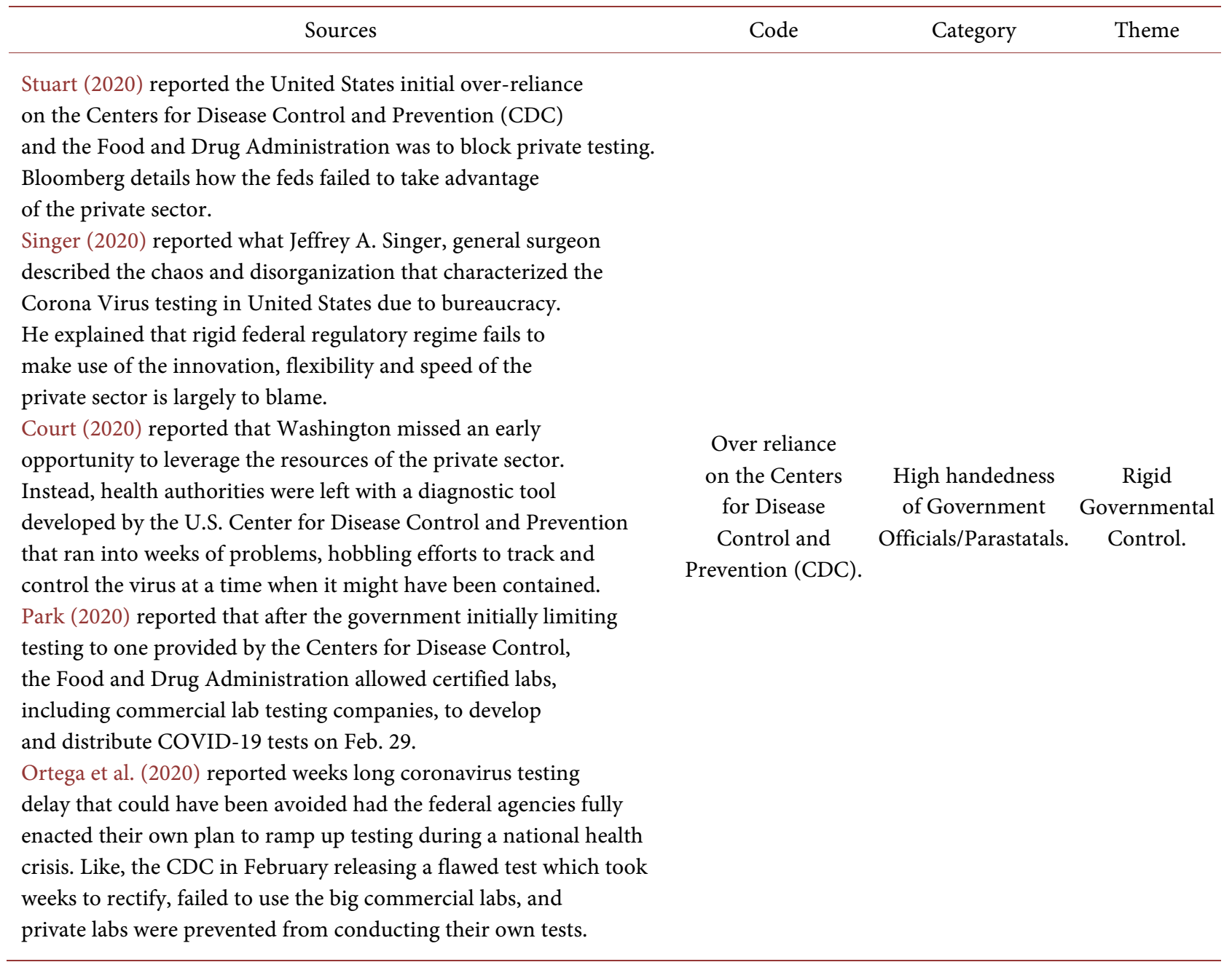

cross-verification before themes eventually emerged. The dependability was ensured by the accurate citing of sources of secondary data, and the confirmability of the paper was ensured via accurate citing of secondary information, which provided an audit trail. I also used cross verification of data from multiple sources and ensured that data are trending towards the same conclusions before they were included as credible data sources.

\section{Results}

The data collected was used to answer the two central research questions for the paper. However, it is pertinent first to establish that there was a delay in the private sector involvement in the coronavirus testing as identified in the data. Court (2020) reported that Washington missed an early opportunity to leverage the resources of the private sector. Singer (2020) explained that a rigid federal regulatory regime fails to use of the innovation, flexibility, and speed of the private sector is largely to blame. Ortega et al. (2020) reported weeks long coronavirus testing delay that could have been avoided had the federal agencies fully 
enacted their own plan to ramp up testing during a national health crisis. Like, the CDC in February releasing a flawed test which took weeks to rectify, failed to use the big commercial labs, and private labs were prevented from conducting their own tests. Fong (2020) reported the need to include the private sector when President Trump press conference announced "New partnership with private sector to vastly increase and accelerate our capacity to test for coronavirus. We want to make sure that those who need a test can get a test very safely, quickly, and conveniently." While Burton (2020) reported Dr. Stephen Hahn of the Food and Drug Administration Commissioner announced the flexible regulatory approach to allow more private companies to conduct more tests without prior approval.

The data clearly showed a delay in the private sector involvement in the coronavirus testing, which led to answering the research question: why did the private sector got delayed/not got delayed in coronavirus testing? The answers to this question were obtained from table one via the process of creating codes to categories and which eventually led to themes. The data showed two reasons why there was a delay in private sector coronavirus testing. The first reason is for political gain to guarantee reelection which was discovered through data analysis which revealed a code that showed that the government downplayed the effects of coronavirus in some instances and also exaggerated their plans and successes in other instances. The code led to the discovery of complacency as a category which explained why the government did not appear to take coronavirus seriously at the beginning of the pandemic. This eventually led to the theme of political gain to guarantee reelection as a motive to keep the government approval rating high.

Stuart (2020) reported President Trump when asked about any worries regarding the coronavirus pandemic on Jan. 22 "No not at all" "And, we're, we have it totally under control," Trump said, "it's one person coming in from China, and we have it under control. It's going to be just fine". Also, in late February, Trump continued on Feb. 26: "Because of all we've done, the risk to the American people remains very low. ... When you have 15 people, and the 15 within a couple of days is going to be down to close to zero. That's a pretty good job we've done." On Feb 28: "It's going to disappear. One day, it's like a miracle, it will disappear."

Goldstein et al. (2020) reported the Rose Garden news conference when the government announced partnering with private companies to set up drive-through coronavirus testing sites. President Trump said the push to let people get tested from their own cars would involve a new Google website to advise consumers about whether they should get tested and where, and big-box companies and drugstores that would host drive-through testing sites in their in their store parking lots. States and federal health workers would staff the sites and perform the testing, officials said. However, several key participants said the administration was overstating the plans, including its scope, timetable and other aspects. Fong (2020) reported President Trump press conference announced "New part- 
nership with private sector to vastly increase and accelerate our capacity to test for coronavirus. We want to make sure that those who need a test can get a test very safely, quickly, and conveniently."

Jones (2020) reported what President Trump said during the Press Conference to announce a national state of emergency on coronavirus. Trump said, "I don't take responsibility at all." He also lavished praises on Swiss drug maker Roche which received FDA patent for a COVID-19 test. While Bohn (2020) reported how Google debunked President conference that said Google was building a website that will notify where to get coronavirus test. Debbie Birx, the White House corona virus response coordinator, showed a flowchart that explained the proposed functionality of the website. However, nobody from Alphabet or Google spoke at the event, but after an hour after the event, Google released a statement on twitter saying Google is not building a nationwide coronavirus screening website, and "we are developing a tool to help triage individuals for Covid-19 testing. Verily is in early stages of development, and planning to roll testing out in the Bay area, with the hope of expanding more broadly over time."

The second reason for the delay in the private sector involvement in coronavirus testing was incompetence. This conclusion was reached via the process of data analysis that led to the discovery of a rigid governmental regulation as a code, which prevented the private sector from being permitted to conduct coronavirus testing at the beginning of the pandemic. The code of rigid governmental regulation resulted into confusion when the CDC botched their early coronavirus testing kit, led to the discovery of a category that showed the government as disorganized to handle the coronavirus pandemic. The disorganized and confused government could not articulate and coordinate their responses effectively, which transitioned into the theme of incompetence. The government was so incompetent that they could not coordinate their activities to properly incorporate the private sector into the coronavirus testing operations at the early stages of the coronavirus pandemic.

Stuart (2020) reported the United States' initial over-reliance on the Centers for Disease Control and Prevention (CDC) and the Food and Drug Administration was to block private testing. Bloomberg details how the feds failed to take advantage of the private sector.

Singer (2020) reported what Jeffrey A. Singer, general surgeon described the chaos and disorganization that characterized the coronavirus testing in the United States due to bureaucracy. He explained that a rigid federal regulatory regime that fails to make use of the innovation, flexibility, and speed of the private sector is largely to blame. And Court (2020) reported that Washington missed an early opportunity to leverage the resources of the private sector. Instead, health authorities were left with a diagnostic tool developed by the U.S. Centers for Disease Control and Prevention that ran into weeks of problems, hobbling efforts to track and control the virus at a time when it might have been contained.

Burton (2020) reported that Dr. Stephen Hahn of the Food and Drug Admin- 
istration Commissioner announced the flexible regulatory approach to allow more private companies to conduct more tests without prior approval. Coombs (2020) reported the confusion that followed the government announcing that private labs to start testing for coronavirus, prompting concerns about cost and insurance co-pays. Pollitz (2020) reported the surprise medical bills that might occur if patients seek testing in an emergency room, even at in-network emergency facility if physicians who work there might not be in-network, and out-of-network commercial lab despite the Congress passing the families first coronavirus Response Act, which made testing available via public health departments and private laboratories.

Diamond (2020) reported President Trump Rose Garden announcement on March 13th when he acknowledged that the initiative to increase testing was disappointing at the start, but he wants to preview a network of drive-thru tests in places like Walmart parking lots "The goal is for individuals to be able to drive up and be swabbed." Wamsley (2020) reported that the U.S government has been sharply criticized for its slow response to the virus, particularly when it comes to testing. Hence, the Trump administration announced a series of measures intended to speed testing by appointing a new federal coordinator to oversee testing and funding.

Stebbins and Comen (2020) reported that the coronavirus pandemic has caught the govt unprepared and led to the government to enlist the private sector for help. And Ortega et al. (2020) reported weeks-long coronavirus testing delay that could have been avoided had the federal agencies fully enacted their own plan to ramp up testing during a national health crisis. Like, the CDC in February releasing a flawed test which took weeks to rectify, failed to use the big commercial labs, and private labs were prevented from conducting their own tests. While Pasternack (2020) also attested to the strategic missteps and the botched rollout of the coronavirus testing. In February, U.S faces an array of problems, including a troublesome rollout of supplies and a complex patchwork of rules about how these supplies can be used.

How did the private sector got delayed/not delayed in coronavirus testing? Table 2 provided evidence of how the government delayed/prevented the private sector from getting involved in the coronavirus testing at the early stages of the pandemic to be a rigid governmental control. The code of over-reliance on the Centers for Disease Control and Prevention (CDC) as the only approved establishment for coronavirus testing was discovered via data analysis, which led to the discovery of a category that explained a degree of high handedness by government officials/parastatals that prevented the early involvement of the private sector, and which eventually led to the theme of rigid governmental control.

Stuart (2020) reported the United States initial over-reliance on the Centers for Disease Control and Prevention (CDC) and the Food and Drug Administration was to block private testing. Bloomberg details how the feds failed to take advantage of the private sector. Singer (2020) reported what Jeffrey A. Singer, general surgeon described the chaos and disorganization that characterized the 
Corona Virus testing in the United States due to bureaucracy. He explained that a rigid federal regulatory regime that fails to make use of the innovation, flexibility, and speed of the private sector is largely to blame. Court (2020) reported that Washington missed an early opportunity to leverage the resources of the private sector. Instead, health authorities were left with a diagnostic tool developed by the U.S. Center for Disease Control and Prevention that ran into weeks of problems, hobbling efforts to track and control the virus at a time when it might have been contained.

Park (2020) reported that after the government initially limiting testing to one provided by the Centers for Disease Control, the Food and Drug Administration allowed certified labs, including commercial lab testing companies, to develop and distribute COVID-19 tests on Feb. 29. And Ortega et al. (2020) reported weeks-long coronavirus testing delay that could have been avoided had the federal agencies fully enacted their own plan to ramp up testing during a national health crisis. Like, the CDC in February releasing a flawed test which took weeks to rectify, failed to use the big commercial labs, and private labs were prevented from conducting their own tests.

Having explained the paper's findings to answer the research questions, the next table (Table 3) provides a comprehensive picture of the themes and the answers to the research questions. The first column states the central research questions and the three themes discovered to answer the research questions, while the second column states the answers to the research questions and how the themes that were used to answer the research questions were discovered.

Table 3. Research findings.

\begin{tabular}{|c|c|c|c|c|}
\hline $\begin{array}{l}\text { Why did the private } \\
\text { sector get } \\
\text { delayed/not get } \\
\text { delayed in } \\
\text { coronavirus testing? }\end{array}$ & $\begin{array}{l}\text { How did the } \\
\text { private sector get } \\
\text { delayed/not } \\
\text { delayed in } \\
\text { coronavirus testing? }\end{array}$ & $\begin{array}{l}\text { Political gain/guarantee } \\
\text { re-election as a theme } \\
\text { to why the private } \\
\text { sector got delayed in } \\
\text { corona virus testing. }\end{array}$ & $\begin{array}{l}\text { Incompetence as a } \\
\text { theme to why the private } \\
\text { sector got delayed in } \\
\text { coronavirus testing. }\end{array}$ & $\begin{array}{l}\text { Rigid governmental } \\
\text { control as a theme to } \\
\text { how the private sector } \\
\text { got delayed in } \\
\text { coronavirus testing }\end{array}$ \\
\hline $\begin{array}{l}\text { 1) Political } \\
\text { gain/guarantee } \\
\text { re-election. } \\
\text { 2) Incompetence }\end{array}$ & $\begin{array}{l}\text { 1) Rigid } \\
\text { governmental } \\
\text { control. }\end{array}$ & $\begin{array}{l}\text { This theme was } \\
\text { discovered from } \\
\text { sources compiled by the } \\
\text { researcher. A code } \\
\text { which showed that the } \\
\text { government down } \\
\text { played the effects of } \\
\text { coronavirus/exaggerated } \\
\text { their plans and successes } \\
\text { was discovered which } \\
\text { resulted into the category } \\
\text { of complacency, which } \\
\text { eventually transitioned } \\
\text { into the theme of } \\
\text { political gain/guarantee } \\
\text { re-election. }\end{array}$ & $\begin{array}{l}\text { This theme was } \\
\text { discovered from } \\
\text { sources compiled by the } \\
\text { researcher. A code that } \\
\text { showed a rigid } \\
\text { governmental regulation } \\
\text { was discovered which } \\
\text { resulted into the } \\
\text { category of } \\
\text { disorganization, } \\
\text { which eventually } \\
\text { transitioned into the } \\
\text { theme of incompetence. }\end{array}$ & $\begin{array}{l}\text { This theme was } \\
\text { discovered from sources } \\
\text { compiled by the } \\
\text { researcher. A code which } \\
\text { showed over reliance on } \\
\text { the Centers for Disease } \\
\text { Control and Prevention } \\
\text { (CDC) was discovered } \\
\text { which resulted into the } \\
\text { category of high } \\
\text { handedness of } \\
\text { government } \\
\text { officials/parastatals, } \\
\text { which eventually } \\
\text { transitioned into the } \\
\text { theme of a rigid } \\
\text { governmental control. }\end{array}$ \\
\hline
\end{tabular}




\section{Discussion}

The searching and compilation of relevant data regarding the coronavirus testing from multiple sources of data were difficult because it is a contemporaneous topic. But the concentration on private sector activities helped me to extract the relevant information from the aggregate data. Inferences were drawn to understand why and how there was a delay in the private sector involvement in coronavirus testing. The deficiencies of the case study did not allow me to quantify the data, as some articles provided more relevant data than the others. However, the case study approach provided an in-depth understanding of the coronavirus from the private sector perspective.

Based on the contemporaneous nature of the topic, I recommend further studies to determine the most important reason why there was a delay in the private sector involvement in the coronavirus testing. It is pertinent to understand whether the need for political gain to guarantee reelection led to the incompetence of the government or the incompetence of the government led to the need for political cover. Gangel et al. (2020) reported President Donald Trump admitted he knew weeks before the first confirmed U.S coronavirus death that the virus was more dangerous, airborne, highly contagious, and "more deadly than even your strenuous flus" and repeatedly played it down publicly, according to legendary journalist Bob Woodward in his new book "Rage". This statement supports the theme of political gain to guarantee reelection. And the implication is that if the quest for political gain led to the government's incompetence, governmental actions on coronavirus might be criminal because thousands of deaths might have been prevented if there were adequate and efficient responses to the pandemic. Also, the activities of the government might be considered as mala administration if the incompetency of the government influenced the political cover to guarantee reelection. Therefore, it is pertinent to investigate which theme influenced the other between the quest for political gain to guarantee reelection or the government's incompetence to respond efficiently to the coronavirus pandemic.

This paper has confirmed Osinowo (2019) postulation, who stated that "the government has enormous power to influence public policy to compel private companies to abide by its directives." This paper showed how the government deliberately delayed the early involvement of the private sector in coronavirus testing. It also showed that the private sector provided little or no resistance even when they possess human and material resources to develop their own coronavirus testing kit. These revelations imply that the government has not provided adequate mechanisms to integrate the private sector in the public policy process. Equally, the private sector has not developed adequate mechanisms to influence the government even when their interests are at stake (profit-making). When the peoples' interests are at stake, early coronavirus testing might have prevented thousands of deaths. This paper has also revealed more than Osinowo (2019) postulation "that it was necessary to include private sector analysis in a compre- 
hensive review of public policy because inter-dependencies of the private-public sector guarantee effective public policy implementation/assessment". This paper affirms that it should be compulsory to include the private sector in the public policy process because their expertise is needed to provide expedited public policy to cater to societal needs.

\section{Conclusion}

This paper was about the use of a case study approach to provide an in-depth understanding of a particular case of why and how the private sector got delayed in the coronavirus testing in the United States of America. The purpose of the paper is to investigate the synergy between the public and private sectors in coronavirus testing. The paper's goal is to help to cement or reject the need for the private sector in public policy via the study of coronavirus testing. The significance of the study showed the importance/influence of the private sector in public policy formulation, execution, and evaluation by using coronavirus testing as the unit of analysis. Although the deficiencies of the case study as a qualitative approach to the research did not allow me to quantify the data, it provided an in-depth understanding of the coronavirus testing from the private sector perspective. The paper revealed two reasons why there was a delay in the private sector involvement in coronavirus testing to be the quest by the government to seek political gain to guarantee reelection, and the incompetence of the government that could not incorporate and coordinate the early inclusion of the private sector in coronavirus testing. The paper also revealed how the government delayed the private sector involvement in the coronavirus testing via a rigid governmental control that denied the private sector the opportunity to conduct coronavirus testing at the early stages of the pandemic.

Based on the above findings, the first take-home message is that the government possesses enormous power on public policy and can prevent the private sector that is also a stakeholder in public policy, the ability to get involved in the public policy process. There are no adequate mechanisms to guarantee easy integration and coordination between the private and the public sector in public policy. Hence, I recommend a policy change that will create adequate mechanisms or frameworks that will guarantee easy integration and coordination between the private and the public sectors for better policy formulation and implementation. The second take-home message is to effect a positive social change, and I conclude that it is compulsory to include the private sector in the public policy process. The rationale for this conclusion is that it was evident from the research results that had the government engaged the private sector early in the coronavirus testing, and the botched coronavirus testing at the beginning of the pandemic would have been avoided. And this would have been easily realizable if the government had provided adequate mechanisms/platforms which would have guaranteed easy integration and coordination between the private and the public sector. Hence, the private sector expertise is needed to provide expedited public policy to cater to the needs of society. 


\section{Conflicts of Interest}

The author declares no conflicts of interest regarding the publication of this paper.

\section{References}

Basit, T. (2003). Manual or Electronic? The Role of Coding in Qualitative Data Analysis. Educational Research, 45, 143-154. https://doi.org/10.1080/0013188032000133548

Bohn, D. (2020). Contrary to Trump's Claim, Google Is Not Building a Nationwide Coronavirus Screening Website. The Verge. https://www.theverge.com/google-coronavirus-testing-screen

Burton, T. M. (2020). FDA to Allow Private Companies to Market Coronavirus Test Kits without Prior Approval. The Wall Street Journal.

https://www.wsj.com/articles/fda-to-allow-private-companies

Centers for Disease Control and Prevention (2020). About COVID-19/CDC. https://www.cdc.gov/coronavirus/2019-ncov/cdcresponse

Coombs, B. (2020). Private Labs Start Testing for Coronavirus, Prompting Concerns about Cost and Insurance Co-Pays. CNBC.

https://www.cnbc.com/2020/03/06/private-labs-start-testing-f

Court, E. (2020). In Coronavirus Testing Ramp-Up, U.S. Called Private Sector in Late. Bloomberg. https://www.bloomberg.news/articles/coronavirus-te

Creswell, J. (2009). Research Design: Qualitative, Quantitative, and Mixed Methods Approaches (3rd ed.). Sage Publications.

Creswell, J. W. (2013). Qualitative Inquiry \& Research Design: Choosing among Five Approaches (2nd ed.). Sage Publications.

Diamond, D. (2020). How a 96-Hour Project Helped Trump's Team Reverse Its Testing Debacle. Politico. https://www.politico.com/2020/05/05/coronavirus-t

Fong, T. (2020). Trump Administration Highlights Role of Private Sector in Effort to Increase Coronavirus Testing. GenomeWeb. https://www.genomeweb.com/policy-legislation/trump-admin

Gangel, J., Herb, J., \& Stuart, E. (2020). 'Play it down': Trump Admits to Concealing the True Threat of Coronavirus in New Woodward Book. CNN. https://www.cnn.com/2020/09/09/politics/bob-woodward-r

Goldstein, A., McGinley, L., \& Abutaleb, Y. (2020). Trump Says He Will Partner with Private Sector to Expand Coronavirus Testing but Details Are Sketchy. The Washington Post. https://www.washingtonpost.com/health/2020/03/13

Hyman, D. (2014). Public Finance: A Contemporary Application of Theory to Policy (11th ed.). Cengage Learning.

Jones, S. (2020). To Trump, America Is Just a Series of Corporate Fiefdoms. New York Magazine. https://www.nymag.com/intelligencer/2020/03/thanks-to-trump-c

Liamputtong, P., \& Ezzy, D. (2005). Qualitative Research Methods (2nd ed.). Oxford University Press.

Ortega, B., Bronstein, S., Devine, C. \& Griffin, D. (2020). How the Government Delayed Coronavirus Testing. CNN.

https://www.cnn.com/coronavirus-testing-cdc-fda-red-tape-invs

Osinowo, G. A. (2019). Internet and Telecommunications Companies' Provision of Customer Information to the Government. Ph.D. Dissertation, Walden University. 
Park, A. (2020). The First U.S. Company Has Announced an Upcoming Home COVID-19 Test. Time. https://www.time.com/Health/COVID-19

Pasternack, A. (2020). Inside the Coronavirus Testing Mess that Ruined Our Chance to Stop the Pandemic. Fast Company. https://www.fastcompany.com/these-companies-are-scrambling

Pollitz, K. (2020). Private Health Coverage of COVID-19: Key Facts and Issues. https://www.kff.org/coronavirus-covid-19/issue-brief/pri

Saldana, J. (2013). The Coding Manual for Qualitative Researchers (2nd ed.). Sage Publications.

Singer, J. A. (2020). Coronavirus Testing Delays Caused by Red Tape, Bureaucracy and Scorn for Private Companies. NBC News.

https://www.nbcnews.com/think/opinion/coronavirus-test

Stebbins, S., \& Comen, E. (2020). US Companies Dominate List of Those Landing Largest COVID-19 Contracts with the Government. USA Today.

https://www.usatoday.com/story/money/2020/06/16/30

Stuart, A. (2020). In Early Stages of Coronavirus Fight, the Private Sector Was Ready to Help, but the Federal Government Didn't Let It. Reason Foundation.

https://reason.org/commentary/in-early-stages-private-sect

Wamsley, L. (2020). Trump Administration Announces Measures to Speed Coronavirus Testing. NPR. https://www.npr.org/sections/health-shots/2020/03/13/tru

World Health Organization (2021). Coronavirus. World Health Organization. https://www.who.int/Healthtopics

Yin, R. (2014). Case Study Research-Design and Methods (5th ed.). Sage Publications. 